\title{
DEVALUATIONS AND DEPRECIATION EXPECTATIONS IN THE E.M.S.
}

Juan Ayuso y María Pérez Jurado 


\section{DEVALUATIONS AND DEPRECIATION EXPECTATIONS IN THE E.M.S.}

Juan Ayuso and María Pérez Jurado (*)

(*) The authors are grateful to Fernando Restoy for his comments and suggestions. They would also like to thank J. J. Camio, C. Melcón, J. L. Vega and J. Viñals for their comments, and F. Alonso and J. J. Pacheco for their research assistance.

Banco de España - Servicio de Estudios

Documento de Trabajo no 9531 
In publishing this series the Banco de España seeks to disseminate studies of interest that will help acquaint readers better with the Spanish economy.

The analyses, opinions and findings of these papers represent the views of their authors; they are not necessarily those of the Banco de España.

ISSN: 0213-2710

ISBN: 84-7793-456-8

Depósito legal: M-7810-1996

Imprenta del Banco de España 


\begin{abstract}
This paper proposes a method to estimate separately the size of the expected depreciation in an eventual devaluation of the central parity in the ERM, and the probability assigned by agents to this devaluation occurring in the short run. The proposed method, complements the information provided by the jumps observed in market exchange rates around realignments with the information contained in interest rate differentials on the future behaviour of exchange rates. The separation of probability and size allows a richer analysis of the effects of devaluations on exchange rate credibility in the ERM.
\end{abstract}





\section{INTRODUCTION}

The Exchange Rate Mechanism (ERM) of the European Monetary System (EMS) sets fluctuation bands for the bilateral exchange rates of participating currencies around central parities that can be realigned under the consensual decision of member countries. Since the creation of the System, the exchange rates have fluctuated either around the central parity or around another reference parity also located within the band in force. The credibility conferred by agents on the future maintenance of the central parity and/or the effective fluctuation regime within the band is a decisive determinant in attaining the objectives sought when joining the exchange rate mechanism. Not surprisingly, papers analysing this credibility $^{1}$ have proliferated.

The credibility indicators proposed in these studies generally focus on estimations of the expected devaluation rate (or of the associated rate of depreciation of the market exchange rate), this rate being the product of two components: the probability assigned to a devaluation occurring, and the expected size of the accompanying change in the central parity (or in the market exchange rate).

However, breaking down credibility indicators into their two basic components provides a way of tackling problems that cannot be solved by using the aggregate information derived from the expected rate of devaluation. Thus, on the one hand, Ayuso, Pérez Jurado and Restoy (1995) show that, if perfect credibility in the exchange rate fluctuation regime does not exist, the conventional (GARCH-type) volatility indicators underestimate the exchange rate risk. To obtain a satisfactory measure, these indicators must incorporate a correction factor, whose calculation must take into account not only the degree of credibility measured by the expected depreciation rate but also an estimate of the size component.

1 Svensson (1991) and Bertola and Svensson (1993) are two seminal papers in the construction of credibility indicators. Examples of their application can be found in Rose and Svensson (1991), Holden and Vikoren (1992), Lindberg, Söderlind and Svensson (1993), Caramazza (1993), and Ayuso, Pérez Jurado and Restoy (1993), among others. 
In addition, the analysis of the probability component is especially pertinent to the study of certain aspects of credibility that may remain hidden if the aggregate indicator is used. This is clearly exemplified in a question that has important implications for economic policy, namely the impact of devaluations on credibility. Drazen and Masson (1994) analyse the possible effects of devaluations on credibility, and, on a theoretical plane, they conclude that the consequences depend on the relative importance of two contrary effects: the reputation effect, which would tend to reduce the credibility of the monetary authority, and the disequilibria correction effect, which would enhance the credibility of the economic policies implemented by the monetary authority.

Conventional credibility indicators that do not disagregate the two components are again inappropriate for determining how agents evaluate devaluations. In general, a devaluation (when it implies an effective depreciation) will reduce the expected size of the jump in the exchange rate associated with a further devaluation. However, the impact of a devaluation on the probability component is a priori ambiguous. Therefore, devaluations that are accompanied -thanks to the magnitude of the depreciation- by subsequent reductions in the expected rate of devaluation could, nonetheless, mask credibility losses by the monetary authorities. This loss of credibility, by contrast, would be reflected in an increase in the probability assigned by agents to another devaluation occurring.

The goal of this paper is to develop a method for obtaining separate estimates of the two components in the expected rate of depreciation associated with a devaluation, and, from there, to analyse the probability behaviour, focusing especially on the developments surrounding a devaluation.

Although few studies have attempted to separate probability and size, two in particular may be referrenced to in this paper: Gutiérrez (1994) and Mizrach (1993). In the first, the size component represents the changes in central parities arising from realignments. This does not allow using the information about the future behaviour of market exchange rates contained in interest rate differentials. Such information 
is especially useful in this case because, by the very nature of the exchange rate agreement, devaluations are highly infrequent phenomena, and it is therefore difficult to draw any type of inference based exclusively on observed exchange rates ${ }^{2}$. The second paper uses these differentials, but does not draw on the information contained in the jumps observed in market exchange rates around realignments, and instead makes the decomposition solely on the basis of the different functional form in the size (linear) and the probability (non-linear) components.

The main innovation of the proposed method of estimation is that it complements the information on the future behaviour of exchange rates contained in the interest rate differentials between homogeneous assets denominated in different currencies with the information on the size component provided by the jumps in market exchange rates around realignments.

The paper is structured as follows. Section 2 develops an econometric model that provides the basis for estimating the two components that are measured jointly in the conventional credibility indicators: the probability of future devaluations and the expected size of the associated jump in the market exchange rate. Section 3 estimates and analyses the size component, while section 4 studies the evolution of the probability component, with special emphasis on the impact of devaluations thereon. Section 5 presents a simple model to explain probability in the case of the peseta. Lastly, section 6 outlines the main conclusions of the paper.

2 In the literature, these difficulties have been generally dubbed the peso problem. See Krasker (1980). 
2. AN ECONOMETRIC MODEL FOR ESTIMATING THE PROBABILITY OF A DEVALUATION AND THE EXPECTED SIZE OF THE ASSOCIATED DEPRECIATION

As is usual in the credibility literature, we begin by characterizing the behaviour of the exchange rate in the context of univariate models. Concretely, we assume that the stochastic process followed by the (logarithm of the) market exchange rate $-s_{t}-$ is:

$$
s_{t}=k+\Gamma(L) s_{t-1}+d_{t}+\epsilon_{t}
$$

where

$$
d_{t}=\left\{\begin{array}{l}
d_{t}^{*}, \text { with prob. } p_{t-1} \\
0, \text { with prob. } 1-p_{t-1}
\end{array}\right.
$$

and $\Gamma(L)$ is a polynomial of order $q$ in the lag operator $L$. The variable $d_{t}^{*}$ measures the size of the jump in the market exchange rate (depreciation) associated with a devaluation, and $p_{t-1}$ is the probability at moment $t-1$ that, at moment $t$, the devaluation will occur.

We also assume that the depreciation associated with a devaluation the first of the variables intended for estimation- depends on the variables in the vector $\mathrm{X}_{\mathrm{t}-\mathrm{i}}^{\mathrm{d}}$ :

$$
d_{t}^{*}=X_{t-1}^{d} \beta^{d}+u_{t}^{d}
$$

The devaluation occurs when a given indicator $-C_{t}-$, (which can be interpreted as an excess cost for the authorities derived from maintaining the prevailing parity) takes a positive value. This indicator depends on the variables in the vector $\mathrm{X}_{\mathrm{t}-1}^{\mathrm{c}}$ :

$$
C_{t}=X_{t-1}^{c} \beta^{c}+u_{t}^{c}
$$

The estimation of the relevant parameters in this equation allows us to estimate the probability that a devaluation will occur in the following period, given that 


$$
\left.p_{t-1}=\operatorname{Prob} \cdot\left(u_{t}^{c}\right)-X_{t-1}^{c} \beta^{c}\right)
$$

Lastly, we assume that the joint distribution of the random shocks $u_{t}^{d}$ and $u_{t}^{c}$ is normal with zero-mean and variance matrix $\Sigma$

$$
\Sigma=\left(\begin{array}{cc}
d_{d}^{2} & \sigma_{c d} \\
\sigma_{c d} & \sigma_{c}^{2}
\end{array}\right)
$$

However, neither the indicator $C_{t}$ nor the variable $d_{t}$ is directly observable. The only available information is the sign of $C_{t}$ (i.e. whether or not a devaluation occurs) and, if it actually occurs, the size of the corresponding depreciation in the market exchange rate $d_{t}^{*}$. If the variable $\omega_{t}$ is defined as

$$
\omega_{i}= \begin{cases}1, & \text { if } C_{t}>0 \\ 0, & \text { if } C_{t} \leq 0\end{cases}
$$

the observable variables are $\omega_{t}$ and $d_{l}^{*} \forall t / \omega_{t}=1$.

The estimation of the parameters of equation (1) on the basis of a sample that only includes the jumps in the market exchange rate observed when a devaluation has occurred entails a problem of sample selection (see Amemiya 1985). If the shocks in equations (1) and (2) are not independent, for the estimator of $\beta^{d}$ and $\sigma_{d}$ to be consistent, a new regressor which depends on the parameters and variables in equation (2), must be added to equation (1):

$$
d_{t}^{*}=X_{t-1}^{d} \beta^{d}+\lambda\left(X_{t-1}^{c} \beta^{c} / \sigma_{c}\right) \theta+\epsilon_{t}, \quad \forall t / \omega_{t}=1
$$

where

$$
\lambda\left(X_{t-1}^{c} \beta^{c} / \sigma_{c}\right)=\frac{\phi\left(X_{t-1}^{c} \beta^{c} / \sigma_{c}\right)}{\Phi\left(X_{t-1}^{c} \beta^{c} / \sigma_{c}\right)}
$$

is known as the Heckman's lambda, $\Phi$ and $\phi$ are the distribution and density functions of the standard normal, respectively, and, as shown in 
Amemiya (1985), $\epsilon_{i}$ is not homoskedastic. Therefore, the estimation of the expected size of the depreciation associated with a devaluation requires the prior estimation of equation (2), which determines the corresponding probability.

However, the estimation of devaluation probabilities on the basis of equation (2) proves quite complicated, for two reasons: first, the variables that make up the vector $x_{t-1}^{c}$ must be determined and measured $^{3}$, and, second, it is difficult to detect their foreseeably high volatility on the basis of the scant number of observed devaluations (the well-known peso problem). Both problems can be at least partly alleviated by incorporating in the analysis the information on expected future exchange rates contained in the interest rate differential between two homogeneous assets denominated in each of the currencies considered.

The non-existence of arbitrage opportunities in financial markets implies the following relationship of parity between interest rates:

$$
\begin{gathered}
i_{t-1}-i_{t-1}^{*}-E_{t-1}\left(\Delta s_{t} \mid \omega_{t}=0\right)-\rho_{t-1}=P_{t-1}\left(\omega_{t}=1\right) E_{t-1}\left(d_{t}^{*}\right)= \\
=\Phi\left(X_{t-1}^{c} \beta^{c} / \sigma_{c}\right) X_{t-1}^{d} \beta^{d}
\end{gathered}
$$

where $i_{t-1}$ and $i_{t-1}^{*}$ are the (not annualized) interest rates of two assets that mature in the following period and are denominated in the corresponding currencies, and $\rho_{t-1}$ is an exchange rate risk premium.

Equation (4) can be used to remove $\beta^{c} / \sigma_{c}$ and $X_{t-1}^{c}$ from equation $(3)^{4}$. Specifically, this equation can be rewritten as where

and $\Phi^{-1}$ is the inverse function of $\Phi$.

3 The probability assigned by agents that a devaluation will occur most likely depends on a broad set of factors, not necessarily all of an economic nature -political events, for instance- or easily measurable.

- Alternatively, equation (4) could be used to remove the variables and parameters related to the expected size. In principle, however, the sizes are likely to be comparatively less volatile than the probabilities and, therefore, easier to explain in terms of the $\mathrm{X}$ variables. 


$$
\begin{gathered}
d_{t}=X_{t-1}^{d} \beta^{d}+f\left(X_{t-1}^{d} \beta^{d}\right) \theta+v_{t} \\
f\left(X_{t-1}^{d} \beta^{d}\right)=\frac{\phi\left[\Phi^{-1}\left(\Omega_{t-1} / X_{t-1}^{d} \beta^{d}\right)\right]}{\Omega_{t-1} / X_{t-1}^{d} \beta^{d}} \\
\Omega_{t-1}=i_{t-1}-i_{t-1}^{*}-E_{t-1}\left(\Delta s_{t} \mid \omega_{t}=0\right)-\rho_{t-1}
\end{gathered}
$$

The non-linear equation (5) -where the variables and parameters of equation (2) are no longer present- can be estimated by using an iterative method whose steps are summarized below:

1. Estimate by ordinary least squares the linear regression

$$
d_{t}^{*}=X_{t-1}^{d} \beta^{d}+\xi_{t}, \quad \forall t / \omega_{t}=1
$$

i.e. for observations corresponding to episodes of devaluation.

2. After estimating the expected size of the jump in the market exchange rate, $E_{t-1}\left(d_{t}^{*}\right)=d_{t}^{*}$, use equation (4) to estimate the probability of devaluation $^{5}$

$$
\mathrm{P}_{\mathrm{t}-1}\left(\omega_{\mathrm{t}}=1\right)=\frac{\Omega_{\mathrm{t}-1}}{\hat{\mathrm{d}}_{\mathrm{t}}^{*}}
$$

Note that this method of estimating probability is an alternative to using equation (2), whereby:

$$
\mathrm{P}_{\mathrm{t}-1}\left(\omega_{\mathrm{t}}=1\right)=\Phi\left(\mathrm{X}_{\mathrm{t}-1}^{\mathrm{c}} \beta^{\mathrm{c}} / \sigma_{\mathrm{c}}\right)
$$

Therefore, $\Omega_{t-1} / \hat{d}_{t}^{*}$ provides an estimation of $\Phi\left(X_{t-1}^{c} \beta^{c} / \sigma_{c}\right)$ where it was not necessary to specify the variables in the vector $X_{t-1}^{c}$.

5 If the resulting probability is negative (higher than unity), it is estimated to take a value of 0 ( 1 ). 
3. Use this estimation of $\Phi\left(X_{t-1}^{c} \beta^{c} / \sigma_{c}\right)$, to obtain $\phi\left(X_{t-1}^{c} \beta^{c} / \sigma_{c}\right)$. The quotient of the two expressions provides an alternative estimate of the regressor $\lambda\left(X_{t-1}^{c} \beta^{c} / \sigma_{c}\right)$ to that obtained from a direct estimation of equation (2).

4. Estimate equation (3) including here the variable $\lambda\left(X_{t-1}^{c} \beta^{c} / \sigma_{c}\right)$ estimated in step 3 . If the maximum (absolute) difference between the new vector $\hat{\boldsymbol{\beta}}^{\mathrm{d}}$ and the previous one exceeds some critical level, the iterative method is repeated as from 2 with the new estimated size.

In short, thanks to the incorporation of the information content of the interest rate differential, the proposed method minimises the problems derived from the existence of a peso problem. Further, it also simplifies the procedure for calculating the probability of devaluation and the size of the associated depreciation, insofar as it reduces the set of explanatory variables that must be incorporated into the analysis. In the next section, this method is applied to estimate the expected size of the depreciations associated with the devaluations that have occurred since the creation of the EMS.

\section{ESTIMATION OF THE EXPECTED SIZE}

This section uses the model described in the previous section to estimate the expected size of the depreciations associated with possible devaluations in the sample, which runs from 13 March 1979, when the EMS $^{6}$ was created, to 31 August 1994. This estimation requires several other assumptions, which are discussed below.

First, there is a still open debate on the existence of mean reversion in the process followed by ERM exchange rates. Neither the usual tests on the stationarity of the exchange rate series -even allowing

6 For currencies that joined the exchange rate mechanism at a later date, the sample begins at the time of their incorporation: 19-6-89 for the peseta and 6-4-92 for the escudo. The case of the British pound is not considered, since it has never undergone a devaluation against the Dmark. 
for different means along the sample- nor the results in the literature offer a clear answer. In any case, Chen and Giovannini (1992) point out the difficulties in testing the properties of the process followed by the exchange rates in absence of realignments, from their observed evolution between realignments.

In Ayuso, Pérez-Jurado and Restoy (1996) a different approach is proved in orden to get an approximate idea of the degree of mean reversion in the exchange rate series. Assuming that there have not been expectations of revaluation against the D-mark, they find that the maximum mean reversion compatible with such assumption is well below .002. Therefore, we assume that, in the absence of expected devaluations, random walks can approximate reasonably well the processes followed by exchange rates. We also assume that uncovered interest rate parity (UIP) holds, and thus the exchange rate risk premia $-\rho_{t}-$ are assumed to be null. UIP is supported by several studies, at least with respect to ERM currencies ${ }^{7}$, which are those considered in this paper.

As to the specific data included in the estimation, it must be noted, first, that daily frequency is used in order to maximize the number of available observations. With respect to exchange rates, given that the $D-$ mark is generally acknowlleged to be the anchor of the System we focus on the size of the jumps in bilateral exchange rates vis-à-vis this currency. The interest rates used in equation (4) are the 1-month deposit rates on the Euromarket, denominated in the currencies analysed. Note that the spread between lending rates with a 1-month maturity provides information on the probability and expected size of the jump -which we assume to be unique- at this horizon.

For every devaluation, a number of associated 1-month jumps can be observed in the market exchange rate that is equal to the number of daily data contained in the 1 -month period immediately prior to the devaluation. Each of these jumps is obtained by calculating the difference between the market exchange rate on each day of the month prior to the

7 See Ayuso and Restoy (1996) and Svensson (1992). 
devaluation and the rate registered exactly one month after that date. In this way, the use of daily frequency allows us to obtain -for each currency and each realignment- some 22 daily observations ${ }^{8}$ of the size of the jump. Table 1 shows the size of the jumps in the central parities and in the market exchange rates around these devaluations. Altogether, the sample includes 36 realignments $^{9}$, implying a total of 672 observations.

As to the possible variables for explaining size, the fact that central parities can only be realigned with the mutual agreement of all member countries of the ERM was taken into account. Thus, all countries are assumed to share a common criterion that will logically attempt to prevent competitive devaluations. In characterizing these "rules of the game", which should be mirrored in the associated jumps in market exchange rates, several factors were considered. First, the sizes depend on the accumulated losses in competitiveness. These losses are approximated by the deviation in the real exchange rate against the $D$ mark from a reference real exchange rate ${ }^{10}$.

Second, the need for a consensus does not necessarily rule out some flexibility to enable the specific conditions in each country to be considered. This characteristic is incorporated by allowing the real exchange rate coefficient to vary not only between countries but also over time, depending on other variables that reflect these conditions and which are generically denoted as $Z_{t}$. Specifically, three variables are

8 There are, on average, 22 market days in a month.

9 Due to problems of data availability, the first two devaluations of the Danish krone and the first three devaluations of the Irish pound had to be excluded from the 46 that occurred between 1979 and 1994. Also excluded were five other cases (two for the Belgian franc, two for the Danish krone and one for the Irish pound) in which the respective market exchange rate appreciated against the D-mark.

10 Both measured by consumer price indices. The component for relative prices in this time series is available on a monthly -but not a daily-basis. Here, as in the rest of this paper, monthly variables were converted into daily ones by repeating for each day the previous day's data until reaching a new monthly figure. 
considered: a medium-term national interest rate (the rate of 3-year public debt), the rate of unemployment, and the anchor country's interest rate (1-year).

Therefore equation (1) can be written as

$$
d_{i, t}^{*}=\beta_{i}+\beta_{i, t-1}\left(q_{i, t-1}-\bar{q}_{i}\right)+u_{i, t}
$$

where

$$
\beta_{i, t-1}=\delta_{0}+\delta_{1}\left(Z_{1, t-1}-\bar{z}_{1}\right)
$$

and the parameters must meet the following restrictions

$$
\beta_{1, t-1} \geq 0 \forall i, \forall t, \delta_{0} \geq 0, \delta_{1} \geq 0
$$

The subscript $t$ represents the time (in days); the subscript $i$ refers to the System's eight currencies that -aside from the D-mark- have undergone a realignment, i.e. the French franc, Belgian franc, Danish krone, Italian lira, Irish pound, Dutch guilder, Spanish peseta and Portuguese escudo; $q_{t}$ is the real exchange rate against the $D$-mark; $\bar{q}_{1}$ is the real exchange rate of reference for each currency, and $\mathrm{Z}_{1, t}$ and $\overline{\mathrm{Z}}_{1}$ are, respectively, the current and reference levels of the variable $Z$, measured in such a way that they are always nonnegative. The behaviour that this model aims to reflect is the possibility that the greater a given macroeconomic imbalance, the greater will be the reaction of the expected size to a given loss in competitiveness.

Rearanging terms, the preceding equation is transformed to the following linear equation for the size of the depreciations associated with devaluations:

$$
d_{i, t}^{*}=\gamma_{0, i}+\gamma_{1} q_{i, t-1}+\gamma_{2, i} z_{i, t-1}+\gamma_{3, i} q_{i, t-1}+\gamma_{4} z_{i, t-1} q_{i, t-1}+u_{i, t}
$$

where the parameters must meet the following restrictions 


$$
\begin{aligned}
& \gamma_{1}=\delta_{0} \geq 0 \\
& \gamma_{2, i}=-\delta_{1} \bar{q}_{i} \leq 0 \\
& \gamma_{3, i}=-\delta_{1} \bar{z}_{i} \leq 0 \\
& \gamma_{4}=\delta_{1} \geq 0
\end{aligned}
$$

Using equation (6) and the interest rate differentials, the parameters $\gamma$ are estimated under the iterative method described in the previous section. The convergence criterion of the iterative process was set at $10^{-6}$. The main results are presented in Tables 2 and 3 . As Table 2 shows, none of the variables used to characterize possible differences in the sensitivity of the size of the jumps to the real exchange rate produces satisfactory results. One or more of the restrictions of sign is violated and/or the coefficient of the real exchange rate is not statistically significant. In the case of the 3-year national interest rate, the constant term of the real exchange rate coefficient has an incorrect sign, although, as in the case of the variable term, it is not statistically significant. The results based on the unemployment rate are no better and, in addition to violating several non-negativity restrictions, the estimated sizes are extraordinarily high ${ }^{11}$. Lastly, neither the constant nor the variable component of the real exchange rate coefficient is significant when the German interest rate is used as the $\mathrm{Z}$ variable. However, as we shall later see, some of these variables do play an important role in explaining the probability of a devaluation. In any case, the model that best fits the data is the one in which the sensitivity of size to changes in competitiveness is constant. The results for this model are given in Table 3.

Table 3 shows that, when considered constant over time and between countries, the sensitivity of the expected size of the depreciation to losses in competitiveness is $24 \%$. The coefficient is statistically significant and correctly signed. However, the coefficient of Heckman's lambda is not significant, thus showing that there is little correlation

${ }^{11}$ By way of example, sizes exceding $14 \%$ are obtained for the Danish krone in the 1990s. 
between the innovations in the probability equation and the innovations in the size equation. Consequently, the problem of sample selection is not overly relevant in this case ${ }^{12}$.

The parameters in Table 3 allow the construction of a continuous time series of expected sizes for each currency as from the time of its entry into the ERM. Chart 1 reflects this evolution and compares the estimated sizes of the depreciations with those that actually occurred after realignmens. As can be seen, due to the nature of the variable that is being explained (a movement in an exchange rate) and the simplicity of the model considered (one constant per country and a single explanatory variable whose coefficient does not vary between countries), the model reasonably fits the (average) jumps associated with the devaluations of the central parities against the D-mark. The fit is particularly good for some countries, such as Denmark, but not very convincing in cases such as the Dutch guilder. Notable, too, are the model's difficulties in fitting the sizes of the depreciations that occurred as a result of the System's last generalized realignment in January 1987. Additionally, throughout the sample the values of the expected size for each currency move within what can be considered reasonable limits.

\section{THE PROBABILITY OF DEVALUATION}

To obtain the probability of a devaluation within the next month, we use the information contained in the euromarket 1 -month interest rate differentials $\left(i_{t-1}-i_{t-1}^{*}\right)$ and the sizes estimated in the preceding section $\hat{d}_{t}^{*}=E_{t-1}\left(d_{t}^{*}\right)$. Thus, in line with equation (4) and using the aforementioned assumptions, the probability series are obtained from

$$
P_{t-1}\left(\omega_{t}=1\right)=\frac{i_{t-1}-i_{t-1}^{*}}{\hat{d}_{t}^{*}}
$$

12 In fact, the direct estimation of equation (1), which does not include Heckman's lambda, provides practically the same estimates. 
Since the interest rate differential provides information on the probability of devaluation for each day of the sample, this method has the great advantage of preventing the possible bias in an estimation of such a probability based on a sample of $\omega_{t}$, -which only takes into account when devaluations do or do not occur ${ }^{13}$. However, the shortcoming of this method is that it does not impose a priori the restriction that the probability must belong to the interval $[0,1]$, and, therefore, it is essential to check, first of all, whether the results are coherent in this respect.

The probabilities calculated under the method described do, in general, belong to the interval $[0,1]$. They only exceed these limits in very small percentages of the corresponding samples, ranging from $0.6 \%$ for the Danish krone and the Italian lira to $6.9 \%$ for the Belgian franc. Moreover, in the latter case, it is nearly always a question of negative values, whose minimum $(-0.04)$ is very close to zero, that are involved. These percentages do not take into account either the Dutch guilder or the escudo when it belonged to the $\pm 15 \%$ band. In the case of the guilder, the probability is practically null throughout the sample, with values ranging between -0.001 and 0.002 . In the case of the escudo, the model seems to give a particularly bad fit in the period in question, because higher-than-unity probabilities are very frequently obtained. This could be due to the fact that the number of devaluations for this currency -only two- was very small and that, in one of them, the market exchange rate underwent practically no change at 1 -month horizon. That would give rise to a clear underestimation of the expected size and, consequently, to an overestimation of the probability. For these reasons, the probability of devaluation for the guilder and that for the escudo when it belonged to the wide band are not presented, nor are they taken into account in the analysis below.

${ }^{13}$ The high volatility that foreseeably characterizes these time series would be very difficult to detect on the basis of the observed frequency of realignments. This has been shown in other studies, and is corroborated in the estimations presented below. 
First, in subsection 4.1, a descriptive analysis of devaluation probabilities is given. Second, subsection 4.2 examines the behaviour of these probabilities when realignments occur.

\subsection{A descriptive analysis of ralignment probabilities}

Chart 2 presents the monthly averages of the estimated daily probabilities of devaluation (at 1 month). These time series reflect several common patterns among the different currencies. Thus, for currencies for which the sample begins with the creation of the ERM (Chart 2a), the generalized realignment of March 1983 marks a clear change in the pattern of probability trends. The probabilities in the period prior to this date reflect higher averages and variances than are later observed, thus reaching significantly higher maximum values ${ }^{14}$. This result seems consistent with the fact that, until this date, the realignments in the System were much more frequent. Numerous papers (see, for example, Lambertini, Miller and Sutherland, 1992, and Thygesen, 1988) have highlighted this turning point in the development of the $\mathrm{ERM}^{15}$.

After that, the probabilities of devaluation were downwards in all cases, with several interruptions corresponding to periods of tension. The decline observed in devaluation probabilities even placed the currencies that had remained in the narrow band since 1979 at practically null values prior to the eruption of the crisis in the autumn of 1992 . Notably, the Belgian franc was the currency that benefitted the longest from this period of great stability. At the other extreme, the lira failed to see a similarly sharp decline in its devaluation probability.

${ }^{14}$ This phenomenon also appears in the few studies in the literature that measure devaluation probabilities (see Mizrach, 1993, and Gutiérrez, $1994)$.

15 The period prior to March 1983 has been characterized as a stage in which the prevention of misalignments in real exchange rates was a greater concern than the need to reduce inflation rates, where realignments were very frequent and where, therefore, the System lacked a nominal anchor. In fact, in the four and a half years after the creation of the EMS, practically no progress was made in the convergence of inflation rates, and 56\% of the devaluations analysed occurred in this period. 
The devaluation probabilities of the peseta and the escudo did not reflect null values at any time either in the sample. The first one, however, began trending clearly downwards after joining the ERM, and this pattern persisted until the days prior to the negative results of the first Danish referendum on the Maastricht Treaty (June 1992), -a date that has of ten been signalled as the starting point of the subsequent turmoil in the ERM. By contrast, the devaluation probability of the escudo, which joined the System shortly after that date, trended upwards almost immediately after its entry.

The numerous episodes of tension since September 1992 (actually, on the whole, upward trends were observed as of June 1992) are reflected in average increases in devaluation probability in all cases, although, logically, of varying intensity and frequency. By way of example, two days before the devaluation of the Italian lira in September 1992, its probability of devaluation reached its highest value in five years.

At the end of the sample, after the widening of the fluctuation bands, devaluation probabilities returned to the levels of stability that prevailed before the Danish referendum, except in the case of the peseta, the only currency that later -2 March 1995- underwent a devaluation ${ }^{16}$. In any event, in the absence of a sufficient number of devaluations in the new stage of $\pm 15 \%$ bands, there is no way of testing whether a structural change occurred in the model, and thus the latter finding should be interpreted with caution.

\subsection{The impact of devaluations}

One question with important implications for economic policy is the impact that the devaluations have on credibility. In this respect, in deciding on devaluations, it is essential to consider whether this measure will ease market tensions or, on the contrary, will exacerbate them. However, the theory is not conclusive as to the sign of their effect. The traditional credibility models underscore the reputation effect of economic policy measures, under which a devaluation would constitute a signal of

16 Recall that the escudo is not considered in this period. 
"weak" authority and would, therefore, tend to heighten the probability of further devaluations. However, as Drazen and Masson (1994) point out, the probability assigned to a devaluation should reflect not only the reputation of the authorities but also the state of the economy; even a "strong" government may wish -or, rather, be forced- to devalue if the circumstances are adverse enough.

Hence, a devaluation, via the reputation effect, can cause agents to lower their perception of the level at which the authorities are unwilling to bear the cost of a non-devaluation policy, thereby increasing the probability of further devaluations. However, insofar as a devaluation places the exchange rate at levels more in line with economic fundamentals and reduces the cost of maintaining the exchange rate commitment, the probability that a future shock may lead to another devaluation will diminish.

Thus, in theory, devaluations can have two contrary effects on the probability of devaluation. Determining which of the two will predominate is an empirical question that can be analysed by comparing the estimated level of this probability before and after each of the devaluations within the ERM during the period under study.

Table 4 presents the probability of devaluation before and after realignments. Given the upward tendency observed before realignments, the average of the previous week is compared with the average of the following month ${ }^{17}$. The time span of a month is used here, since it is short enough to prevent other effects from entering into play and, at the same time, is long enough to avoid drawing conclusions exclusively on atypical values. Of the 41 cases considered, in 25 the probability diminishes after the devaluation and in 16 it increases. Thus, both the effect of the reduction in the cost of maintaining the exchange rate regime (giving rise to a negative sign) and the reputation effect (positive) appear to be relevant, and, in principle, no conclusions can be drawn as to the relative importance of each one.

17 Qualitatively, the results do not change if the average of the previous month, rather than the previous week, is considered. 
However, two empirical regularities are clearly detected that could prove of great interest in view of their implications. Chart 3 was designed to capture the first. It shows that probability increased after a realignment in cases where pre-devaluation probability was less than $10 \%$. Conversely, devaluations that were preceded by high probabilities (more than $40 \%$ ) witnessed a subsequent decrease in probability. Moreover, in general terms, a negative relationship between the degree of anticipation and the subsequent increase in the probability of a devaluation seems to predominate. All told, this appears to indicate that the more the agents anticipate a devaluation, the more the effect of the correction of fundamental disequilibria will predominate. Conversely, "surprise" devaluations tend to heighten the probability that further devaluations will occur, since in this case the loss of reputation effect predominates.

Second, a predominance of the positive impact (increase in probability) of the devaluations is observed in realignments affecting only one or two currencies. Indeed, in 10 out of a total 13 cases of this type, the probability rises after the devaluation. The only exceptions are the realignments of the Irish pound (1-2-93) and of the peseta and the escudo (14-5-93). These exceptions occur in very sizeable devaluations and/or shortly after very sizeable devaluations.

In any event, apart from these exceptions, the results reflect a predominance of the reputation effect in devaluations that do not form part of a generalized realignment. In such cases, it seems logical that a devaluation policy is more readily identified as a sign of weak government. Notably, at the other extreme, a paradigmatic example is the French franc, the only currency that has never undergone a devaluation on its own and also the only one whose devaluations have always been followed by a decrease in probability.

To summarize, from the analysis of the devaluation probabilities around realignments it can be deduced that: both the loss of reputation and disequilibria correction effects are relevant; in general, devaluations with a greater element of surprise tend to increase the probability of a further devaluation due to the predominance of the reputation effect; conversely, the greater the degree of anticipation of a realignment in 
central parities, the more the macroeconomic disequilibria correction effect tends to predominate, while relatively moreanticipated devaluations having a positive impact on credibility; lastly, single devaluations send a clearer signal of weakness, and, in such cases, the impact of the loss of reputation leads to an increase in the probability of further devaluations.

\section{A MODEL FOR THE DEVALUATION PROBABILITY OF THE PESETA}

As noted in section 2, one of the advantages of the method proposed in this paper is that it allows us to estimate separately the probability of a devaluation and the size of the associated depreciation, without having to specify the concrete variables that determine the behaviour of the probability component. Nevertheless, the empirical regularities encountered in the preceding section provide useful information on the type of variables that should be taken into account in the framework of the equation (2) of excess cost. Notwithstanding this new information, specifying an econometric model to explain the behaviour of the devaluation probabilities of ERM currencies remains an overly ambitious task. Nonetheless, it may well be worth drawing on part of the findings in section 4 to estimate a model, necessarily incomplete, for a specific currency. Taking into account the periods of currency turmoil, the case of the peseta would seem appropriate, in that it is a paradigmatic example of the combination of the effects detected, which are summarized below.

Among the empirical regularities detected in section 4, three stand out as particularly relevant because of their implications for the type of variables that should be included in the probability equation. First, the probability patterns of the currencies analysed are similar, possibly reflecting the influence of the general performance of the System. Second, the existence of a reputation effect entails an increase in the probability component after a devaluation, whereas, due to this effect, not devaluing should reduce this probability. Lastly, the macroeconomic disequilibria that entail an exchange-rate-commitment cost, i.e. those 
that can be corrected to some extent by a devaluation, should also play a role.

To capture these effects, the following variables were considered in the case of the peseta:

a) Effect of the general performance of the System: the average probability of the currencies that have traditionally maintained stricter regimes (narrower band), i.e. the Belgian franc, the Danish krone, the French franc and the Irish pound.

b) Reputation effect: a truncated trend that takes the value of zero every time a devaluation occurs ${ }^{18}$.

c) Macroeconomic disequilibria effect: first, taking into account the findings in Ayuso, Pérez Jurado and Restoy (1993), we consider the relative prices of Spain and Germany measured in terms of the CPI, the Spanish current-account deficit in relation to GDP, and the cyclical situation of the Spanish economy, represented by the twelve-month growth rate of the industrial production index (IPI) ${ }^{19}$. Second, we also take into consideration the recent experience of the currency crises since the autumn of 1992, in which an important factor appears to be the dilemma posed by the maintenance of an exchange rate commitment when it requires excessive interest rate levels in relation to the economy's cyclical position. For this reason, we also take into account the mediumterm domestic interest rate (3-year public debt) and this interest rate multiplied by the inverse of the IPI growth rate.

${ }^{18}$ The widening of the bands in August 1993 is considered as another devaluation, since it entailed a significant change in the average of the process observed in the peseta's market exchange rate against the $D-$ mark. In any event, the possible existence of a different reputation effect was tested and rejected.

19 The use of the unemployment rate as an alternative for the growth in the IPI does not qualitatively alter the results discussed here. The significance of the variables is, however, slightly lower. 
Lastly, we also use a variable that reflects the position of the peseta in the fluctuation band to test the "vertigo effect" discussed in several studies ${ }^{20}$. Concretely, we use the maximum depreciation limit minus the exchange rate divided by the width of the fluctuation band (depreciation limit minus appreciation limit). The vertigo effect would imply a negative sign of the coefficient for this variable, whereas a positive sign would be consistent with the stabilising effect ("honeymoon") of the fluctuation bands underscored in the traditional literature on target zones.

As to the dependent variable in the model -the probability of a devaluation of the peseta- the peso problem associated with the existence of only three devaluations in a sample containing more than a thousand data makes it virtually impossible to estimate a model on the basis of the dichotomic variable $\omega_{t}$ discussed in section 2 . Consequently, we chose as the dependent variable the devaluation probability for the peseta estimated in section 4. Naturally, the use of an estimated variable, instead of an observed variable, implies that the findings must be interpreted very cautiously. Moreover, the model should not be expected to explain the devaluation probability in a large percentage, given its high volatility in comparison with the generally much smoother behaviour of the candidate explanatory variables, and the above-mentioned difficulties traditionally associated with the modeling of the credibility of exchange rate regimes ${ }^{21}$.

Bearing in mind these caveats, the following (non-linear) equation was estimated for the probability of a devaluation of the peseta in the period spanning 19 June 1989 (when the peseta joined the ERM) to 31 August 1994:

$$
\mathrm{p}_{\mathrm{t}}=\Phi\left(\mathrm{X}_{\mathrm{t}} \alpha\right)+\eta_{\mathrm{t}}
$$

where $p_{t}$ is the (estimated) probability that agents assign at moment $t$ to a peseta devaluation in the period of one month, and $X_{t}$ is

20 Also known as the "divorce" effect. See Bertola and Caballero (1990), Moutot (1992), and Pérez Jurado and Restoy (1993).

21 See, for example, Svensson (1994). 
the vector of the observations on the aforementioned variables, available at the moment $t$.

The vector of parameters $\alpha$ was estimated by the Generalized Method of Moments, using the regressors themselves as instruments. The standard errors calculated are robust both to heteroskedasticity and to autocorrelation up to the order of 22, in accordance with the characteristics of the equation.

The main findings are summarized in Table 5. The first column presents the results obtained when including all the variables considered. The economic policy dilemma is represented by the medium-term interest rate multiplied by the inverse of the growth rate of the IPI. The additive inclusion of these variables separately does not add any additional explanatory power to the model. Relative prices reflect the opposite sign of what would be expected, although their influence is not significant. This variable could be redundant once the rest of the basic variables are included. The loss of competitiveness reflected in the relative prices entails an exchange-rate-commitment cost. However, this cost could be represented insofar as it translates into an external disequilibrium, which in turn will be taken into account insofar as it gives rise to lower real growth. This could also explain the fact that the coefficient of the current-account deficit is not significant, although, in this case, the sign is correct; in other words, increases in the deficit would give rise to a greater probability of devaluation. The second column in Table 5 reflects the results of the specification that includes only the variables with the correct sign. Lastly, the third column presents the model with those variables that appear to contribute significantly to explain the behaviour of the devaluation probability.

As can be seen, significance is found for a set of variables that can be interpreted in the framework of a combination of the aforementioned effects. In some cases, this significance is marginal, not surprisingly given the above-mentioned difficulties in modeling probability.

Thus, in the period considered, there appears to have been a reputation effect, captured by the truncated trend. Specifically, as time 
passed with no devaluation, the probability of devaluation was reduced, but this accumulated reduction was entirely lost when a devaluation took place. Note that, among the devaluations considered, the first one had a greater loss of reputation impact, and, to date, this loss has not been recovered due to subsequent non-devaluation strategies.

There also appears to have been an effect of the general performance of the ERM, since the probability of a devaluation of the peseta reacts to changes in the probabilities of ERM currencies traditionally subject to stricter regimes. This effect can be explained by the agents' perception of the existence of political pressures to prevent these currencies from devaluing against those of other countries with weaker commitments. Thus, in the event of devaluation of stricter-regime currencies against the D-mark, the peseta would be dragged down with them.

A destabilizing effect of the upper limit of depreciation -or vertigo effect- is also found, since the greater proximity of the exchange rate to this limit increases the probability of devaluation. This unfavourable effect of a slide in the exchange rate on credibility could go undetected if its influence is measure by its impact on the expected rate of depreciation associated with devaluations. Note that slides in the exchange rate reduce the expected size of these depreciations. Therefore, a reduction in the size component could more than offset the increase in the probability component, and the expected rate of depreciation would, in fact, diminish. Also, given the non-linear nature of equation (7), the impact of the position in the band on probability becomes more pronounced as the exchange rate moves closer to the maximum depreciation limit. This non-linearity of the vertigo effect has been underscored in the literature.

Lastly, as the experience of recent crises and the observed impact of devaluations seemed to indicate, the findings signal the influence of the cost associated with maintaining the exchange rate commitment. This cost seems to be adequately represented by the economic policy dilemma entailing the need for a level of interest rates consistent with the defence of the commitment but not with the position in the economic cycle. 


\section{CONCLUSIONS}

This paper obtains estimations both for the probability of devaluation against the D-mark of all ERM currencies and for the expected size of the corresponding jump in their bilateral exchange rates. To this end, a method was designed whose main innovation is that the information provided by the devaluations in the ERM to August 1994 is complemented with the information contained in the interest rate differentials in the Euromarket.

The estimations indicate that the expected size of the depreciations associated with devaluations depends on a country constant term and on the accumulated losses in competitiveness against the D-mark. These losses are approximated by the deviations of the corresponding real exchange rate with respect to a reference level that is not necessarily the same for all currencies.

The devaluation probability patterns are similar among currencies, reflecting what could be labelled the general performance of the System effect. Thus, as from the generalized realignment of March 1983, the probabilities of the currencies that joined the ERM at the time of its creation began to trend downwards, and their devaluation probabilities were practically zero in the period just before the ERM crisis in the autumn of 1992 (with the exception of the lira). Neither the peseta nor the escudo attained such small probabilities during this period of great stability. The recurring bouts of tension as from September 1992 are reflected in upswings in probability. At the end of the sample, after the widening of the fluctuation bands to $\pm 15 \%$, devaluation probabilities except in the case of the peseta- returned to the levels of stability that prevailed prior to the negative result of the Danish referendum on the Maastricht Treaty in June 1992. However, this finding should be interpreted with caution, given the impossibility of testing whether or not a structural change occurred as a result of the widening of the bands.

With respect to the devaluations' impact on the probability of a future devaluation, three conclusions should be highlighted. 
1. Both the loss of reputation effect (which increases probability) and that of the correction of macroeconomic disequilibria (which reduces it) are relevant. Thus, the devaluation risk perceived by agents not only depends on their evaluation of the strength of the authorities, but also on the behaviour of the macroeconomic disequilibria that could be alleviated by a devaluation. Therefore, a devaluation, if justified by the existence of these disequilibria, could have a favourable effect on the credibility of the exchange rate regime, and, conversely, a non-devaluation strategy could have adverse effects insofar as these disequilibria accumulate.

2. The loss of reputation effect has tended to predominate in surprise devaluations, whereas, in general, the more the devaluations were anticipated by agents, the greater their calming effect, as a result of the predominance of the macroeconomic disequilibria correction effect.

3. Agents tend to give greater weight to the sign of authorities' weakness implicit in a devaluation when it does not form part of a generalized realignment. In the great majority of devaluations involving only one or two currencies, the reputation effect predominated, and, consequently, this type of devaluation adversely affected credibility.

Also, the estimation of a specific model for the probability of devaluation of the peseta offers the conclusion that this case provides a good example of the combination of the aforementioned effects of reputation, cost associated with fundamental disequilibria and general performance of the System, in addition to a vertigo effect. 


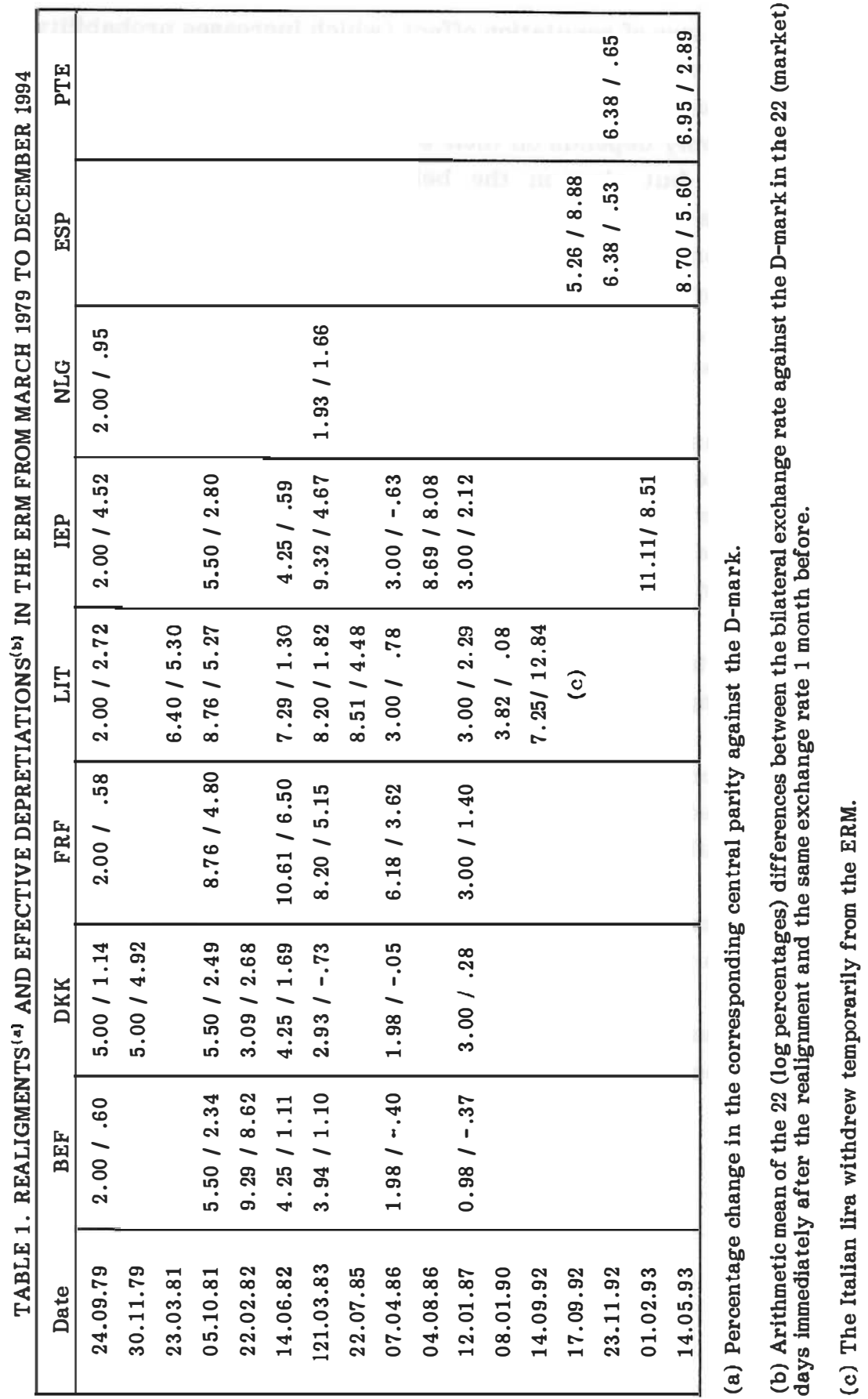


TABLE 2. RELEVANT RESULTS FOR EQUATION (6).

\begin{tabular}{|c|c|}
\hline Variable Z & Main result \\
\hline $\begin{array}{l}\text { Interest rate on 3-year domestic } \\
\text { public debt }\end{array}$ & $\begin{array}{l}\text { The parameters } \gamma \text { have the } \\
\text { correct sign, but: } \\
\hat{\delta}_{0}(\text { t-ratio })=-.23(-.53) \\
\bar{\delta}_{1}(\text { t-ratio })=.04(1.06)\end{array}$ \\
\hline $\begin{array}{l}\text { Unemployment level in each } \\
\text { country }\end{array}$ & $\begin{array}{l}\hat{\gamma}_{2, \mathrm{PIR}} \text { y } \bar{\gamma}_{3, \mathrm{PTE}} \text { are positive and } \\
\text { significant }\end{array}$ \\
\hline 1-year interest rate in Germany & $\begin{array}{l}\text { The parameters } \gamma \text { have the } \\
\text { correct sign, but: } \\
\hat{\delta}_{0}(\text { t-ratio })=.10(.31) \\
\bar{\delta}_{1}(\text { t-ratio })=.03(.66)\end{array}$ \\
\hline
\end{tabular}

NOTES:

- The table includes the results that cause the presence of the corresponding variable $\mathrm{Z}$ in equation (6) to be rejected.

- The t-ratios are obtained from the standard errors robust to heteroskedasticity and autocorrelation up to order 21 . 
TABLE 3. RESULTS FOR THE DEFINITIVE SIZE MODEL

\begin{tabular}{|lc|}
\hline \multicolumn{1}{|c}{ Explanatory variable } & Estimated parameter (t-ratio) \\
\hline Dummy ESP & $-16.22(-1.83)$ \\
Dummy FRF - Dummy ESP & $-2.96(-2.20)$ \\
Dummy BEF - Dummy ESP & $-3.79(-2.49)$ \\
Dummy DKK - Dummy ESP & $-2.84(-2.41)$ \\
Dummy LIT - Dummy ESP & $-0.47(-0.30)$ \\
Dummy IEP - Dummy ESP & $-0.42(-0.33)$ \\
Dummy NLG - Dummy ESP & $-4.18(-2.64)$ \\
Dummy PTE - Dummy ESP & $-7.62(-3.46)$ \\
Real exchange rate & $0.24(2.47)$ \\
Heckman's lambda & $-0.69(-1.41)$ \\
\end{tabular}

\section{NOTES:}

- The t-ratios are obtained from the standard errors robust to heterokedasticity and autocorrelation up to order 21 .

- The number of observations is 672 , and the $R^{2}$ of the model is $30 \%$. 


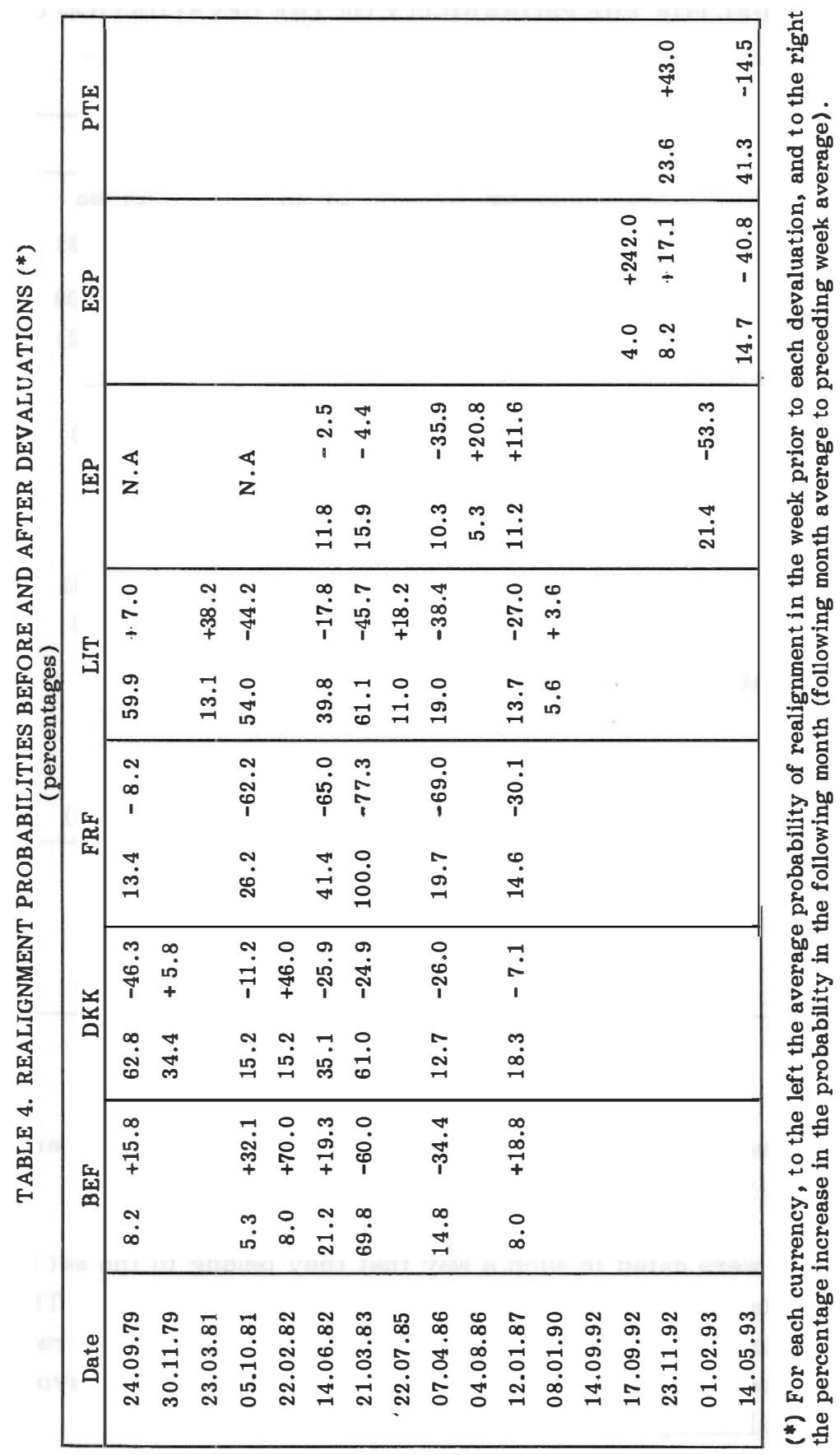


TABLE 5. A MODEL FOR THE PROBABILITY OF THE DEVALUATION OF THE PESETA

\begin{tabular}{|l|c|c|c|}
\hline Explanatory variable & $(1)$ & $(2)$ & $(3)$ \\
\hline Constant & -1.25 & -1.29 & -1.29 \\
Truncated time trend & $(-21.22)$ & $(-26.97)$ & $(-28.33)$ \\
& $-.70 \mathrm{E}-03$ & $-.73 \mathrm{E}-03$ & $-.71 \mathrm{E}-03$ \\
Average probability of & $(-15.52)$ & $(-16.99)$ & $(-16.62)$ \\
other currencies & 1.15 & 1.13 & 1.16 \\
Relative prices & $(3.14)$ & $(2.87)$ & $(2.86)$ \\
& -.43 & --- & --- \\
Dilemma & $(-1.28)$ & & $.12 \mathrm{E}-03$ \\
& $.13 \mathrm{E}-03$ & $.12 \mathrm{E}-03$ & $(2.28)$ \\
Current-account & $(2.54)$ & $(2.18)$ & --- \\
deficit & .28 & .43 & -.12 \\
Position in the band & $(.72)$ & $(1.08)$ & $(-1.86)$ \\
\hline $\mathrm{N}$ & -.17 & -.13 & 1256 \\
$\overrightarrow{\mathrm{R}}^{2}$ & $(-2.10)$ & $(-1.88)$ & .77 \\
$\sigma$ & 1256 & 1256 & $1.32 \%$ \\
\hline
\end{tabular}

NOTES:

- In parenthesis, t-statistics robust to heteroskedasticity and autocorrelation (up to order 22).

- The variables were dated in such a way that they belong to the set of information at the time of forming expectations on the future jump. The interest rate included in the dilemma variable and the exchange rate included in the position variable were lagged an additional period to avoid problems of simultaneity. 
CHART 1a. EXPECTED SIZES (\%)
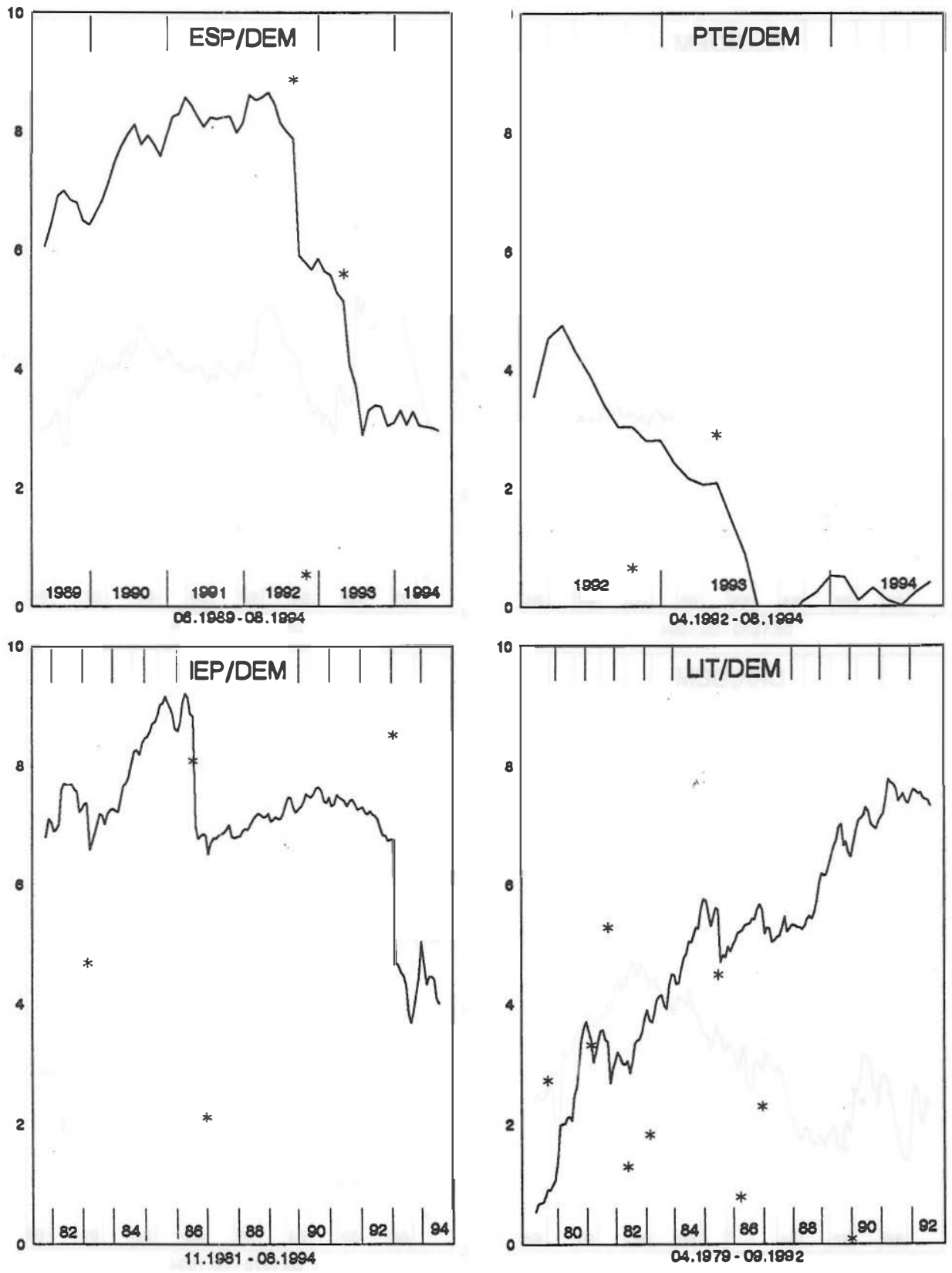

Monthly averages of daily data. In months with devaluations, average of the 22 days inmedlatly prior to them. Asterisks denote the sizes observed in the jumps. 
CHART 1b. EXPECTED SIZES (\%)
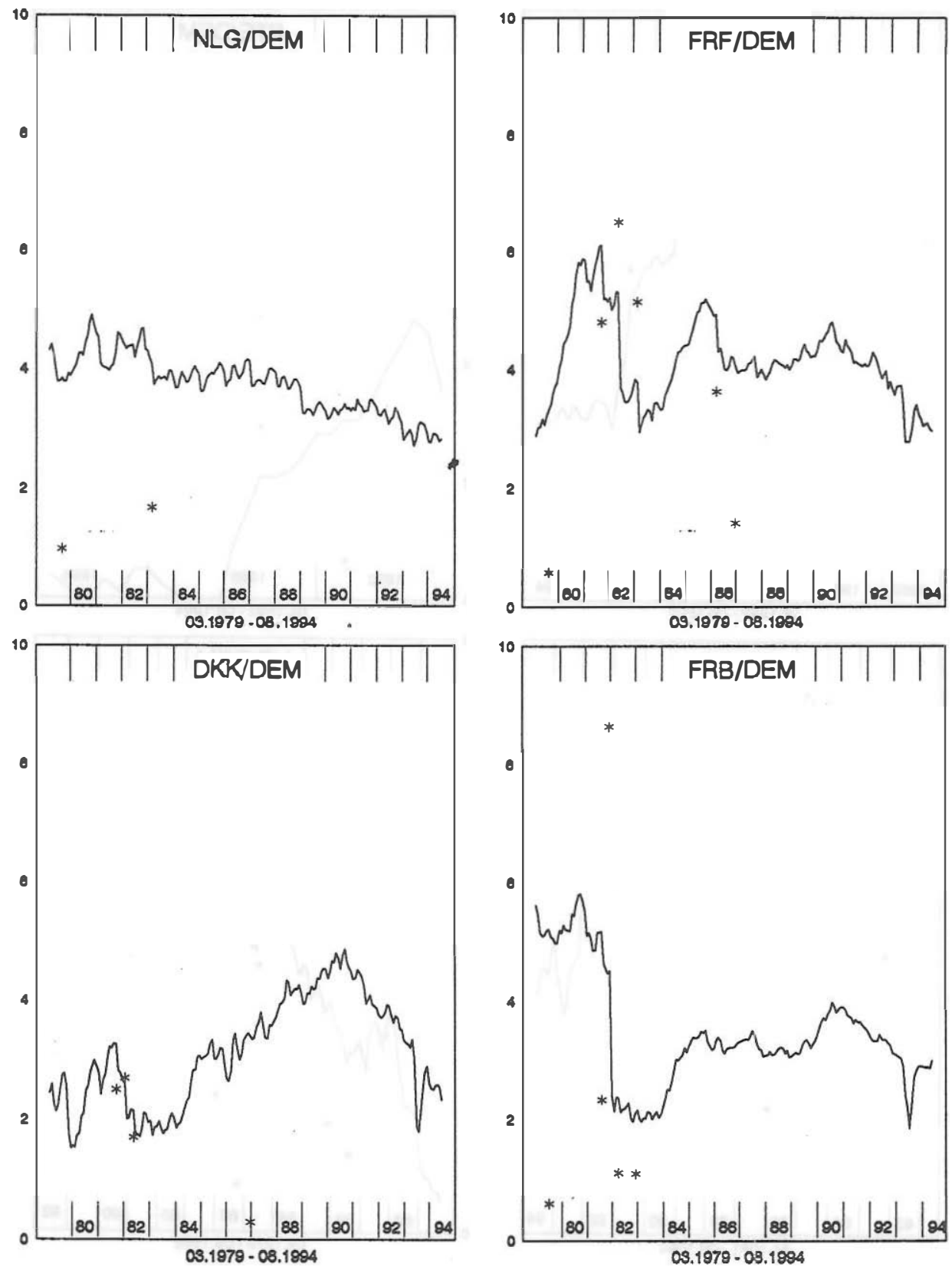

Monthly averages of daily data in months with devaluations, average of the 22 days inmediatly priorto them. Asterisks denote the sizes observed in the jumps. 
CHART 2a. PROBABILITIES
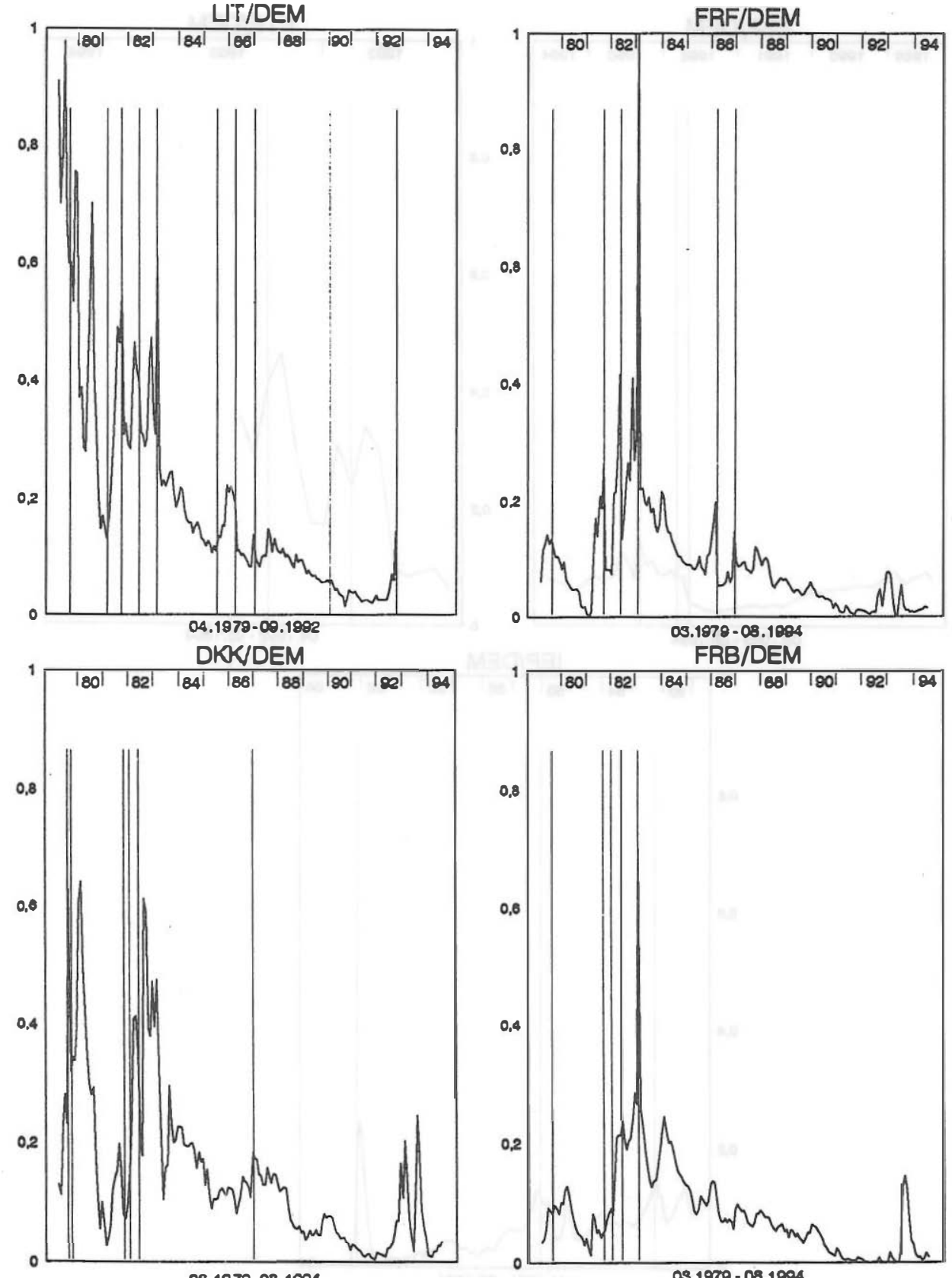

08.1979-08.1894

$03.1979 \cdot 08.1894$

Monthly averages of daily data. In months with devaluations, average of the week inmediatly prior to them. Vertical lines Indicate devaluations. 
CHART 2b. PROBABILITIES

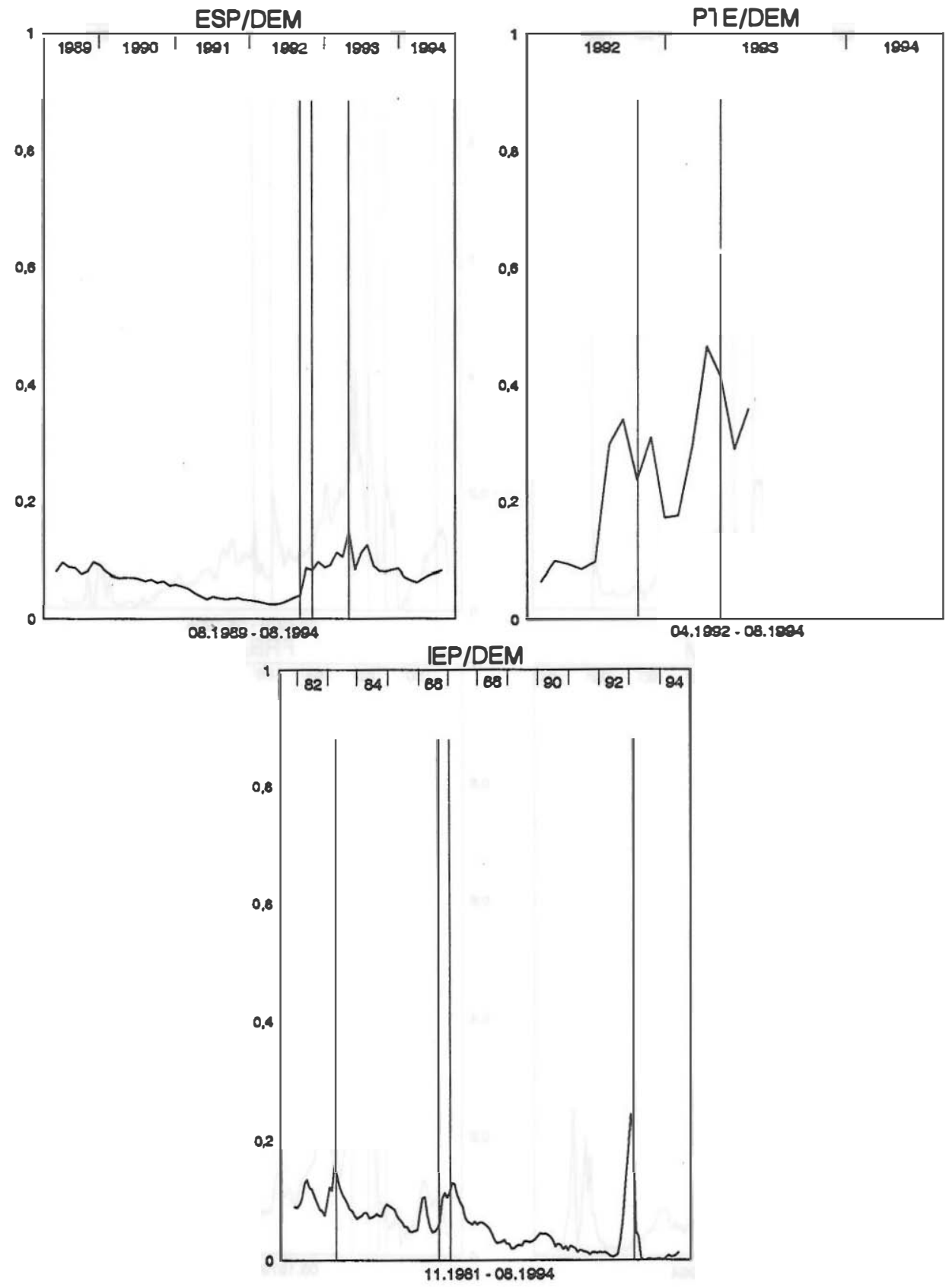

Monthly averages of dally data. In months with devaluations, average of the week inmediatly prior to them. Vertical lines indicate devaluationa. 


\section{CHART 3. PROBABILITY PRIOR TO DEVALUATION}

AND SUBSEQUENT INCREASE

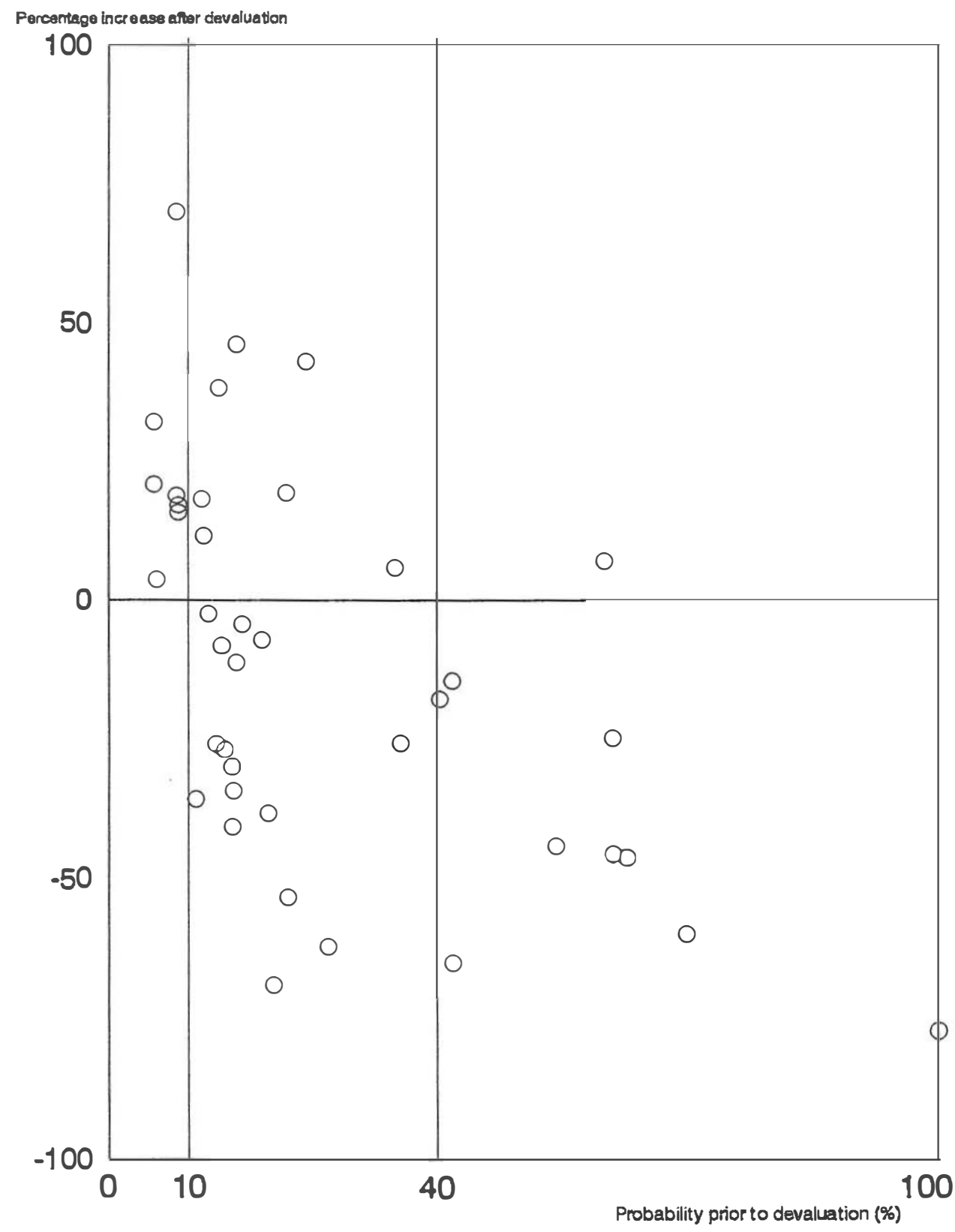





\section{REFERENCES}

Amemiya, T. (1985), Advanced Econometrics, Harvard University Press.

Ayuso, J., M. Pérez Jurado and F. Restoy (1993), "Indicadores de Credibilidad de un Régimen Cambiario: el caso de la Peseta en el SME", Cuadernos Económicos de ICE, 53.

Ayuso, J., M. Pérez Jurado and F. Restoy (1995), "Exchange Rate Risk under a Peso Problem: The Case of the Peseta in the ERM", in European Currency Crisis and After, C. Bordes, E. Girardin and J. Melitz (eds .). Manchester University Press.

Ayuso, J., M. Pérez-Jurado y F. Restoy (1996), "Is exchange rate risk higher in the ERM after the widening of fluctuation bands?", mimeo.

Ayuso, J. and F. Restoy (1996), "Interest Rate Parity and Foreign Exchange Risk Premia in the ERM". Journal of International Money and Finance. Forthcoming.

Bertola, G. and R.J. Caballero (1990), "Target Zones and Realignments", CEPR Discussion Paper Series 398.

Bertola, G. and L.E.O. Svensson, 1993, "Stochastic Devaluation Risk and the Empirical Fit of Target Zone Models", Review of Economic Studies, 60 .

Caramazza, F (1993), "French-German Interest Rate Differentials and Time-varying Realignment Risk", IMF Staff Papers, v. 40, n. 3.

Chen, Z. and A. Giovannini (1992), "Estimating Expected Exchange Rates under Target Zones", NBER Working Paper 3995.

Drazen, A. and P. Masson (1994), " Credibility of Policies vs. Credibility of Policy Makers", Quarterly Journal of Economics, Vol. 109, n. 3.

Gutiérrez, E. (1994), "Un Modelo de Devaluaciones para el SME", CEMFI Working Paper 9416. 
Holden, S. and B. Vikoren (1992), "Have Interest Rates in the Nordic Countries Been Too High? A Test Based on Devaluation Expectations", Norges Bank, Arbeids Notad 1992/6.

Krasker, W.S. (1980), "The 'Peso Problem' in Testing the Efficiency of Forward Exchange Markets", Journal of Monetary Economics, 6.

Lambertini, L., M. Miller and A. Sutherland (1992), "Inflation Convergence with Realignments in a Two-Speed Europe", Economic Journal, 102.

Lindberg, H., P. Söderlind and L.E.O. Svensson (1993), "Devaluation Expectations: the Swedish Krona 1982-1991", Economic Journal, 103.

Mizrach, B. (1993), "Target Zone Models with Stochastic Realignments: An Economic Evaluation", Federal Reserve Bank of New York, Working Paper 93-02.

Moutot, O.P. (1992), "What Might Explain the September 1992 Speculative Attacks on the French Franc?", paper presented at the Se:cond Workshop on Economic Policy Coordination, November 1992.

Pérez Jurado, M. and F. Restoy (1993), "Una nota sobre la estabilidad de la peseta en el SME", mimeo.

Rose, A. and L.E.O. Svensson (1991), "Expected and Predicted Realignments: The FF/DM Exchange Rate during the EMS", Seminar Paper n. 485, IIES, Stockholm.

Svensson, L.E.O. (1994), "European Exchange Rate Credibility before the Fall", Reprint Series n. 510, Institute for International Economic Studies, Stockholm University.

Svensson, L.E.O. (1992), "The Foreign Exchange Rate Premium in a Target Zone with Devaluation Risk", Journal of International Economics, 33. 
Svensson, L.E.O. (1991), "The Simplest Test of Target Zone Credibility", IMF Staff Papers, 38.

Thygesen, N. (1988), Chapter I in Giavazzi, Micossi and Miller (eds.), The European Monetary System, Cambridge, Cambridge University Press. 



\section{WORKING PAPERS (1)}

9310 Amparo Ricardo Ricardo: Series históricas de contabilidad nacional y mercado de trabajo para la CE y EEUU: 196-1991.

9311 Fernando Restoy and G. Michael Rockinger: On stock market retums and returns on investment.

9312 Jesús Saurina Salas: Indicadores de solvencia bancaria y contabilidad a valor de mercado.

9313 Isabel Argimón, José Manuel González-Páramo, María Jesús Martín and José María Roldán: Productivity and infrastructure in the Spanish economy. (The Spanish original of this publication has the same number.)

9314 Fernando Ballabriga, Miguel Sebastián and Javier Vallés: Interdependence of EC economies: A VAR approach.

9315 Isabel Argimón y M. Jesús Martín: Serie de «stock» de infraestructuras del Estado y de las Administraciones Públicas en España.

9316 P. Martínez Méndez: Fiscalidad, tipos de interés y tipo de cambio.

9317 P. Martínez Méndez: Efectos sobre la política económica española de una fiscalidad distorsionada por la inflación.

9318 Pablo Antolín and Olympia Bover: Regional Migration in Spain: The effect of Personal Characteristics and of Unemployment, Wage and House Price Differentials Using Pooled Cross-Sections.

9319 Samuel Bentolila y Juan J. Dolado: La contratación temporal y sus efectos sobre la competitividad.

9320 Luis Julián Álvarez, Javier Jareño y Miguel Sebastián: Salarios públicos, salarios privados e inflación dual.

9.321 Ana Revenga: Credibility and inflation persistence in the European Monetary System. (The Spanish original of this publication has the same number.)

9.322 María Pérez Jurado and Juan Luis Vega: Purchasing power parity: An empirical analysis. (The Spanish original of this publication has the same number.)

9323 Ignacio Hernando y Javier Vallés: Productividad sectorial: comportamiento cíclico en la economía española.

9324 Juan J. Dolado, Miguel Sebastián and Javier Vallés: Cyclical patterns of the Spanish economy.

9325 Juan Ayuso y José Luis Escrivá: La evolución del control monetario en España.

9326 Alberto Cabrero Bravo e Isabel Sánchez García: Métodos de predicción de los agregados monetarios

9327 Cristina Mazón: Is profitability related to market share? An intra-industry study in Spanish manufacturing.

9328 Esther Gordo y Pilar L'Hotellerie: La competitividad de la industria española en una perspectiva macroeconómica.

9329 Ana Buisán y Esther Gordo: El saldo comercial no energético español: deternninantes y análisis de simulación (1964-1992).

9330 Miguel Pellicer: Functions of the Banco de España: An historical perspective

9401 Carlos Ocaña, Vicente Salas y Javier Vallés: Un análisis empírico de la financiación de la pequeña y mediana empresa manufacturera española: 1983-1989.

9402 P. G. Fisher and J. L. Vega: An empirical analysis of M4 in the United Kingdom.

9403 J. Ayuso, A. G. Haldane and F. Restoy: Volatility transmission along the money market yield curve.

9404 Gabriel Quirós: El mercado británico de deuda pública. 
9405 Luis J. Álvarez and Fernando C. Ballabriga: BVAR models in the context of cointegration: A Monte Carlo experiment.

9406 Juan José Dolado, José Manuel González-Páramo y José M. Roldán: Convergencia económica entre las provincias españolas: evidencia empírica (1955-1989).

9407 Ángel Estrada e Ignacio Hernando: La inversión en España: un análisis desde el lado de la oferta.

9408 Ángel Estrada García, M.` Teresa Sastre de Miguel y Juan Luis Vega Croissier: El mecanismo de transmisión de los tipos de interés: el caso español.

9409 Pilar García Perea y Ramón Gómez: Elaboración de series históricas de empleo a partir de la Encuesta de Población Activa (1964-1992).

9410 F. J. Sáez Pérez de la Torre, J. M. Sánchez Sáez y M.` T. Sastre de Miguel: Los mercados de operaciones bancarias en España: especialización productiva y competencia.

9411 Olympia Bover and Ángel Estrada: Durable consumption and house purchases: Evidence from Spanish panel data.

9412 José Viñals: Bu lding a Monetary Union in Europe: Is it worthwhile, where do we stand, and where are we going? (The Spanish original of this publication has the same number.)

9413 Carlos Chuliá: Los sistemas financieros nacionales y el espacio financiero europeo.

9414 José Luis Escrivá and Andrew G. Haldane: The interest rate transmission mechanism: Sectoral estimates for Spain. (The Spanish original of this publication has the same number.)

9415 M.* de los Llanos Matea y Ana Valentina Regil: Métodos para la extracción de señales y para la trimestralización. Una aplicación: Trimestralización del deflactor del consumo privado nacional

9416 José Antonio Cuenca: Variables para el estudio del sector monetario. Agregados monetarios y crediticios, y tipos de interés sintéticos.

9417 Ángel Estrada y David López-Salido: La relación entre el consumo y la renta en España: un modelo empírico con datos agregados.

9418 José M. González Mínguez: Una aplicación de los indicadores de discrecionalidad de la política fiscal a los países de la UE.

9419 Juan Ayuso, María Pérez Jurado and Fernando Restoy: Is exchange rate risk higher in the E.R.M. after the widening of fluctuation bands? (The Spanish original of this publication has the same number.)

9420 Simon Milner and DavidMetcalf: Spanish pay setting institutions and performance outcomes.

9421 Javier Santillán: El SME, los mercados de divisas y la transición hacia la Unión Monetaria.

9422 Juan Luis Vega: Is the ALP long-run demand function stable? (The Spanish original of this publication has the same number.)

942.3 Gabriel Quirós: El mercado italiano de deuda pública.

9424 Isabel Argimón, José Manuel González-Páramo y José María Roldán: Inversión privada, gasto público y efecto expulsión: evidencia para el caso español.

9425 Charles Goodhart and José Viñals: Strategy and tactics of monetary policy: Examples from Europe and the Antipodes.

9426 Carnnen Melcón: Estrategias de política monetaria basadas en el seguimiento directo de objetivos de inflación. Las experiencias de Nueva Zelanda, Canadá, Reino Unido y Suecia.

9427 Olympia Bover and Manuel Arellano: Female labour force participation in the 1980s: the case of Spain. 
9428 Juan María Peñalosa: The Spanish catching-up process: General determinants and contribution of the manufacturing industry.

9429 Susana Núñez: Perspectivas de los sistemas de pagos: una reflexión crítica.

9430 José Viñals: ¿Es posible la convergencia en España?: En busca del tiempo perdido.

9501 Jorge Blázquez y Miguel Sebastián: Capital público y restricción presupuestaria gubernamental.

9502 Ana Buisán: Principales determinantes de los ingresos por turismo.

9503 Ana Buisán y Esther Gordo: La protección nominal como factor determinante de las importaciones de bienes.

9504 Ricardo Mestre: A macroeconomic evaluation of the Spanish monetary policy transmission mechanism.

9505 Fernando Restoy and Ana Revenga: Optimal exchange rate flexibility in an economy with intersectoral rigidities and nontraded goods.

9506 Ángel Estrada and Javier Vallés: Investment and financial costs: Spanish evidence with panel data. (The Spanish original of this publication has the same number.)

9507 Francisco Alonso: La modelización de la volatilidad del mercado bursátil español.

9508 Francisco Alonso y Femando Restoy: La remuneración de la volatilidad en el mercado español de renta variable.

9509 Femando C. Ballabriga, Miguel Sebastián y Javier Vallés: España en Europa: asimetrías reales y nominales.

9510 Juan Carlos Casado, Juan Alberto Campoy y Carlos Chuliá: La regulación financiera española desde la adhesión a la Unión Europea.

9511 Juan Luis Díaz del Hoyo y A. Javier Prado Domínguez: Los FRAs como guías de las expectativas del mercado sobre tipos de interés.

$95 / 2$ José M. ${ }^{2}$ Sánchez Sáez y Teresa Sastre de Miguel: ¿Es el tamaño un factor explicativo de las diferencias entre entidades bancarias?

9513 Juan A yuso y Soledad Núñez: ¿,Desestabilizan los activos derivados el mercado al contado?: La experiencia española en el mercado de deuda pública.

9514 M. Cruz Manzano Frías y M.ª Teresa Sastre de Miguel: Factores relevantes en la determinación del margen de explotación de bancos y cajas de ahorros.

9515 Fernando Restoy and Philippe Weil: Approximate equilibrium asset prices.

9516 Gabriel Quirós: El mercado francés de deuda pública.

9517 Ana L. Revenga and Samuel Bentolila: What affects the employment rate intensity of growth?

9518 Ignacio Iglesias Araúzo y Jaime Esteban Velasco: Repos y operaciones simultáneas: estudio de la normativa.

9519 Ignacio Fuentes: Las instituciones bancarias españolas y el Mercado Único.

9520 Ignacio Hernando: Política monetaria y estructura financiera de las empresas.

9521 Luis Julián Álvarez y Miguel Sebastián: La inflación latente en España: una perspectiva macroeconómica.

9522 Soledad Núñez Ramos: Estimación de la estructura temporal de los tipos de interés en España: elección entre métodos alternativos.

9523 Isabel Argimón, José M. González-Páramo y José M. Roldán Alegre: Does public spending crowd out private investment? Evidence from a panel of 14 OECD countries. 
9524 Luis Julián Álvarez, Fernando C. Ballabriga y Javier Jareño: Un modelo macroeconométrico trimestral para la economía española.

9525 Aurora Ale jano y Juan M.' Peñalosa: La integración financiera de la economía española: efectos sobre los mercados financieros y la política monetaria.

9526 Ramón Gómez Salvador y Juan J. Dolado: Creación y destrucción de empleo en España: un análisis descriptivo con datos de la CBBE.

9527 Santiago Fernández de Lis y Javier Santillán: Regímenes cambiarios e integración monetaria en Europa.

9528 Gabriel Quirós: Mercados financieros alemanes.

9529 Juan Ayuso Huertas: ¿Existe un trade-off entre riesgo cambiario y riesgo de tipo de interés?

9530 Fernando Restoy: Determinantes de la curva de rendimientos: hipótesis expectacional y primas de riesgo.

9531 Juan Ayuso and María Pérez Jurado: Devaluations and depreciation expectations in the EMS.

9532 Paul Schulstad and Ángel Serrat: An Empirical Examination of a Multilateral Target Zone Model.

9601 Juan Ayuso, Soledad Núñez and María Pérez-Jurado: Volatility in Spanish financial markets: The recent experience.

9602 Javier Andrés e Ignacio Hernando: ¿Cómo afecta la inflación al crecimiento económico? Evidencia para los países de la OCDE.

9603 Barbara Dluhosch: On the fate of newcomers in the European Union: Lessons from the Spanish experience.

9604 Santiago Femández de Lis: Classifications of Central Banks by Autonomy: A comparative analysis.

9605 M. ${ }^{a}$ Cruz Manzano Frías y Sofía Galmés Belmonte: Políticas de precios de las entidades de crédito y tipo de clientela: efectos sobre el mecanismo de transmisión.

(1) Previously published Working Papers are listed in the Banco de España publications catalogue.

Queries should be addressed to: Banco de España Sección de Publicaciones. Negociado de Distribución y Gestión Telephone: 3385180 Alcalá, 50. 28014 Madrid 